\title{
To Study the Effect of Sprouted Fenugreek Seeds Along with Yoga and Diet Modification on Obese Patients
}

\author{
Firoz Khan* and Prem Parkash Khosala \\ Department of Pharmacology, Netaji Subhash Chandra Bose Subharti Medical College, \\ India
}

*Corresponding author: Firoz khan, M.Pharm (Pharmacology), Research Scholar, Department of Pharmacology, Netaji Subhash Chandra Bose Subharti Medical College, Subhartipuram NH-58, Delhi Haridwar Bypass Road, Meerut, Uttar Pradesh 250005. Tel:+91-9012537941;E-mail: fkpharmacy@gmail.com

\section{Research Article \\ Volume 3 Issue 3}

Received Date: August 18, 2018

Published Date: September 06, 2018

\section{Abstract}

Background: Obesity is one of the major complications for both morbidity and mortality in the entire world. It can be develop due to change in the lifestyle, reduced social and physical activity, lack of exercise and inactivity to do hard work. However, there are few drugs in the market for the management of obesity but they are costly, less effective and produce side effects as well. So, we need some herbal medicine which has low side effects as well as low coast. Fenugreek is one of the most useful plant which has responsible in the management of obesity and related diseases. Not only whole plant but its seeds are used in the reduction of weight.

Methods: The study was conducted at Maharishi Aurobindo Subharti College \& Hospital of Naturopathy \& Yogic Sciences, Swami Vivekan and Subharti University, Meerut. A total number of 100 patients with obesity were selected. They were grouped into two, group one treatment group (50) consumed 25 gm sprouted fenugreek seeds orally once daily for 45 days and the second group was control (50) not received any dose. In the study from the total 100 individuals, $n=89$ were involved, 39 in treatment group and 50 in the control group. Weight and BMI was measured from each participant before and after the study. Data entry and analysis was performed using SPSS version 20 statistical software. Data were presented as mean \pm SD. A level of $\mathrm{p}<0.05$ was considered statistically significant.

Results: Treatment group had significantly reduced weight and BMI $(\mathrm{P}<0.05)$ compared with baseline weight and BMI of control group.

Conclusions: The present study shows that administration of sprouted fenugreek seeds had pronounced effects on reducing weight and BMI of obese patient with negligible side effects.

Keywords: Sprouted fenugreek seeds; Obesity; Body mass index 


\section{Advances in Pharmacology and Clinical Trials}

\section{Introduction}

The image of the human being has changed significantly in the last fifty years due to changing in lifestyle which involve tendency to increase body weight. Obesity and metabolic disorder characterized by accumulation of excessive fat in the body imbalance between energy intake and expenditure [1].

Overweight and obesity are defined as abnormal or excessive fat accumulation in the body that responsible for development of some metabolic disorders including diabetes, cardiovascular disease, arthritis and many more endocrine diseases [2]. For measurement of obesity and adiposity in the body government proposed a parameter for calculation of obesity or fat in the body which is known as "Body Mass Index". Body mass index (BMI), defined as the weight in kilograms divided by the height in meters squared $\left(\mathrm{kg} / \mathrm{m}^{2}\right)$ [3]. This index commonly used to classify overweight and obesity in adults due to its low cost and simplicity. According to the World Health Organization (WHO); BMI can be calculated on the basis of its BMI range on the table

\begin{tabular}{|c|c|}
\hline Weight status & BMI $\left.\mathbf{( k g} / \mathbf{m}^{\mathbf{2}}\right)$ \\
\hline Underweight & $\leq 18.5$ \\
\hline Normal & $18.5-24.9$ \\
\hline Overweight or pre- obese & $25-29.5$ \\
\hline Obese (Class I) & $30-34.9$ \\
\hline Obese (Class II) & $35-39.9$ \\
\hline Obese (Class III) & $>40$ \\
\hline
\end{tabular}

Table 1: World Health Organization BMI guidelines.

The worldwide prevalence of obesity more than doubled between 1980 and 2017 and for today [4]. WHO has declared obesity as global epidemic and took it under control. In 2014, more than 1.9 billion adults older than 18 years (39\%) are overweight. Overall, about $13 \%$ or 600 million of these adult populations $(11 \%$ of men and $15 \%$ of women) were obese [5]. The highest prevalence of obesity is observed in the Pacific Islands and reach up to $80 \%$ in some regions. The obesity rate less than $1 \%$ has been reported in India [6]. In Europe, as for 2014, in general the incidence of obesity is high but geographically wide variations have been reported. The lowest rate observed in Tajikistan (13.5\%) and highest in Andorra and Turkey (29.4\%) [7]. More than $80 \%$ of countries reported nationally gender-specific data related to prevalence of obesity or over weight in population. In majority of countries located in Africa, Latin America, Asia and Oceania the higher levels of overweight amongst women has been reported. In contrast to these regions in Europe and North America male's overweight prevalence rates were more pronounced [8].

\begin{tabular}{|l|}
\hline (I) Stress-related components \\
\hline - Excessive eating, especially overeating intake of \\
simple sugars \\
\hline • Consumption of cigarettes and tobacco related \\
products \\
\hline - Increase in alcohol and beverages intake \\
\hline $\begin{array}{l}\text { - Nervous and endocrine system related disorders: } \\
\text { increase in the formation of cortisol level, deficiency in } \\
\text { sex hormone secretion }\end{array}$ \\
\hline $\begin{array}{l}\text { (II) Low energy utilization because of an absence of } \\
\text { physical activity/exercise }\end{array}$ \\
\hline (III) Genetic factors \\
\hline (IV) Developing age [9]
\end{tabular}

Table 2: List of related factors to increase obesity.

\section{Fenugreek (Trigonella Foenum-Graecum)}

Fenugreek (Trigonella foenum graecum), native to southern Europe and Asia, is an annual herb with white flowers and hard, yellowish brown and angular seeds, known from ancient times, for nutritional value beside of it medicinal effects. Fenugreek seeds are rich source of gum, fiber, alkaloid, flavonoids, saponin and volatile content [10].

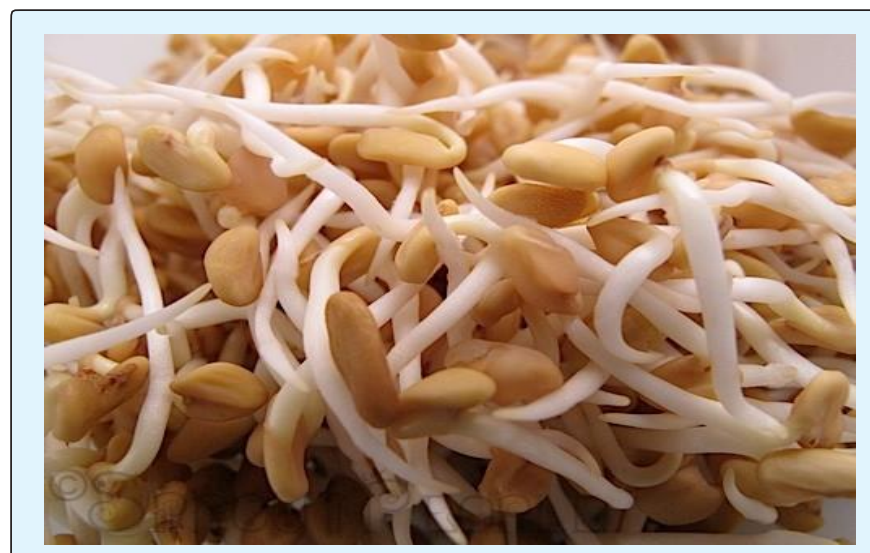

Figure 1: Sprouted fenugreek seeds.

Due to its high content of fiber, fenugreek could be used as food stabilizer, adhesive and emulsifying agent to change food texture for some special purposes. Some evidences suggest that fenugreek may also be regarded as antidiabetic, anticarcinogenic, remedy for hypocholesterolemia and hypoglycemia, antioxidant, antibacterial agent, gastric stimulant, and anti-anorexia agent. The present article is aimed to review the potential 


\section{Advances in Pharmacology and Clinical Trials}

applications of fenugreek as a functional food and nutraceutical [11].

\section{Nutritional Content of Sprouted Fenugreek Seeds}

Sprouts of Trigonella foenum-graecum contains amazing nutritional component for human health by improving the quality standard of food. The sprouts now, used to reduce obesity and metabolic complications because it contains some of the major active ingredients such as- alkaloids, amino acids, flavonoids and large amount of fibre to decrease the absorption of sugar and carbohydrates from the intestine. Here, the list of nutritional component are listed below.

\begin{tabular}{|c|c|}
\hline Alkaloides & $\begin{array}{l}\text { Trigonelline, Trimethylamine, Neurin, } \\
\text { Choline, Gentianine and Carpaine }\end{array}$ \\
\hline Amino acids & $\begin{array}{c}\text { Leucine, Isoleucine, 4-Hydroxyisoleucine, } \\
\text { Histidine, lysine, L-tryptophan, and } \\
\text { Argenine. }\end{array}$ \\
\hline Fibers & $\begin{array}{c}\text { Soluble and insoluble fibers, Gum and } \\
\text { neutral detergent }\end{array}$ \\
\hline Flavonoids & Quercetin, isovetixin, rutin, and vetixin \\
\hline Saponins & $\begin{array}{l}\text { Trigofoenosides A-G, graecunins, } \\
\text { fenugreekine and fenugrin B. }\end{array}$ \\
\hline $\begin{array}{c}\text { Steroidal } \\
\text { sapinogens }\end{array}$ & $\begin{array}{c}\text { Saponaretin, neogitogenin and } \\
\text { yuccagenin }\end{array}$ \\
\hline Other & $\begin{array}{l}\text { Mucilage, lipids, vitamins, proteins, } \\
\text { coumarin and bitter fixed oil [12]. }\end{array}$ \\
\hline
\end{tabular}

Table 3: List of active components in the sprouted fenugreek seeds.

Whereas sprouted fenugreek seeds contains mostly proteins and fibers to facilitate its action by improving the regulation of glucose in the liver or muscular tissue. The content of fenugreek in percentage is listed below [13].

\begin{tabular}{|c|c|}
\hline Component & Percentage (\%) \\
\hline Protein & 32 \\
\hline Crude Fibers & 10.6 \\
\hline Soluble fibers & 20 \\
\hline Insoluble fibers & 28 \\
\hline Fat & 6.24 \\
\hline Ash & 3.14 \\
\hline Water & 7.6 \\
\hline Carbohydrate & 38.7 \\
\hline Moisture content & 13.5 \\
\hline
\end{tabular}

Table 4: Chemical composition of sprouted fenugreek seed (On dry weight basis $\mathrm{mg} / 100 \mathrm{~g}$ ).

\section{Taxonomic Classification of Fenugreek}

\begin{tabular}{|c|c|}
\hline Kingdom & Plantae \\
\hline Subkingdom & Tracheobionta \\
\hline Superdivision & Spermatophyta \\
\hline Division & Magnoliophyta \\
\hline Class & Magnoliopsida \\
\hline Subclass & Rosidae \\
\hline Order & Fabales \\
\hline Family & Fabaceae \\
\hline Genus & Trigonella \\
\hline Species & T. Foenum-graecum \\
\hline
\end{tabular}

Table 5: Taxonomic classification of fenugreek plant [14].

\section{Common Names of Fenugreek in India}

\begin{tabular}{|c|c|}
\hline Botanical Name & Trigonella Foenum-graecum \\
\hline English & $\begin{array}{c}\text { Fenugreek, Sickle Fruit fenugreek, } \\
\text { Greek hay }\end{array}$ \\
\hline Hindi & Methi \\
\hline Sanskrit & Methika \\
\hline Tamil & Vendhayam \\
\hline Telugu & Menthulu \\
\hline
\end{tabular}

Table 6: Different names of fenugreek in India.

\section{Morphology}

1. Appearance: Seeds are solid- rhomboidal, 3 to $5 \mathrm{~mm}$ long to $2 \mathrm{~mm}$ thick, soft, pebble-like.

2. Colour: Yellowish brown or light brown

3. Odour: Characteristic spicy

4. Taste: Slightly bitter and mucilaginous [15].

\section{Materials and Methods}

\section{Study Area}

Design of the study was open labelled and carried out on 100 already diagnosed patients; were suffering from obesity and metabolic syndrome (increased BMI). Patients met with the inclusion criteria enrolled for the study. The study was carried out under the supervision of Maharishi Aurobindo Subharti College \& Hospital of Naturopathy \& Yogic Sciences, Swami Vivekan and Subharti University, Meerut (U.P). All the patients were duly informed about the research work, possible effects and known side effects of sprouted fenugreek seeds. The patient was enrolled in the study with their own interest, and a written informed consent was taken from everyone. The duration of this study was 45 days. An approval of 


\section{Advances in Pharmacology and Clinical Trials}

Institutional ethics committee was obtained before the start of the study.

\section{Experimental Design}

Design: Open labelled study.

Patients were divided into two groups:

Group 1 (Treatment group): Patients were given the standard treatment protocol that was Yoga, diet advice and 25gm sprouted fenugreek seeds for 45 days.

Group 2 (Control Group): Patients were on normal routine; except Yoga, diet and sprouted fenugreek seeds.

Parts of plant used: Sprouted fenugreek (Trigonella foenum-graecum) seeds.

Dose used: $25 \mathrm{gm}$ of sprouted fenugreek seeds once daily.

\section{Eligibility Criteria}

\section{Inclusion Criteria}

- Subject diagnosed with obesity (BMI $>25$ ).

- Age 18-50 years

- Patients were not taking any Ayurvedic or allopathic medicine for obesity

- Presence of dyslipidemia or non dyslipidemia.

- Presence of increased cholesterol levels.

\section{Exclusion Criteria}

- Patients who are not willing to participate in the study and unable to give informed Consent.

- Patient having liver diseases.

- Patients with ischemic heart disease.

- Patient with any diabetic complications such as neuropathy, nephropathy, or retinopathy.

- Pregnant women.

\section{Sampling Technique}

Patients satisfied for the eligibility criteria were randomized to treatment and control groups. The treatment group received $25 \mathrm{gm}$ of sprouted fenugreek seeds once daily along with Yoga and diet modification for 45 days, while controls group did not received any dose of fenugreek sprouts.

\section{Response Rate}

A total of 100 patients were enrolled for the study, 89 completed the study, 39 in treatment group and 50 in the control group, but some dropped out of the study: 6 patients in first two weeks, 5 patients in second two weeks for reasons unrelated to the use of sprouted fenugreek seeds and for its taste.

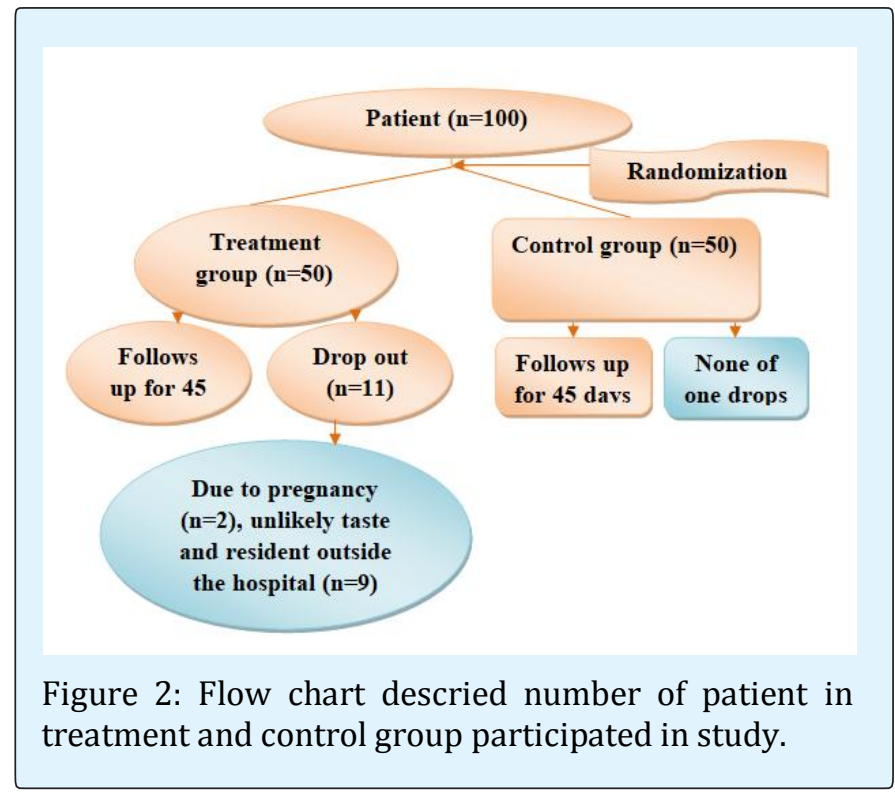

\section{Prepared Yoga (Asana) Chart}

Patients were advised to follow the given Asana (Yoga) chart as exercise for 45 days for reduces the weight.

\begin{tabular}{|c|c|c|}
\hline Sr. No. & Asana Name & Number of Sets \\
\hline 1 & Surya Namaskar & $3-5$ \\
\hline 2 & Tadasana (Mountain Pose) & 2 \\
\hline 3 & Vrikshasana (Tree Pose) & 2 \\
\hline 4 & $\begin{array}{c}\text { Adho Mukho Svanasana } \\
\text { (Downward Facing Dog Pose) }\end{array}$ & $3-4$ \\
\hline 5 & Trikonasana (Triangle Pose) & $8-10$ \\
\hline 6 & Kursiasana (Chair Pose) & $5-6$ \\
\hline 7 & Naukasana (Boat Pose) & $5-6$ \\
\hline 8 & Bhujangasana (Cobra Pose) & $10-11$ \\
\hline 9 & Paschimottanasana & $6-7$ \\
\hline 10 & Sukhasna & $8-9$ \\
\hline
\end{tabular}

Table 7: Yoga chart for obese subjects.

\section{Diet Chart for Obese Subjects}

Along with Yoga, patient were on diet control and was followed the diet as directed in the informed consent for 45 days. 


\section{Advances in Pharmacology and Clinical Trials}

\begin{tabular}{|c|c|}
\hline Food Item & Amount \\
\hline Early Morning & Yoga (30-50 mins) \\
\hline Tepid Water & $2-3$ glass \\
\hline Sprouted Fenugreek Seeds & 3 table spoon (aprox. $25 \mathrm{mg}$ ) \\
\hline Lemon Tea & $1 \mathrm{cup}$ \\
\hline Fiber Biscuits OR & 2 \\
\hline $\begin{array}{l}\text { Cucumber Shake Or } \\
\text { Vegetable Shake }\end{array}$ & 1 medium bowl \\
\hline \multicolumn{2}{|l|}{ Breakfast } \\
\hline \begin{tabular}{|c|} 
Stuffed Green \\
Methi/Palak/Lauki Paratha \\
Or Roti
\end{tabular} & 2 small \\
\hline \begin{tabular}{|c|} 
Curd \\
\end{tabular} & 1 cup (50 gm) \\
\hline \multicolumn{2}{|l|}{ Or } \\
\hline $\begin{array}{c}\text { Vegetable } \\
\text { Poha/Upama/Oats/Daliya }\end{array}$ & 1 soup bowl \\
\hline \multicolumn{2}{|l|}{ Mid Morning } \\
\hline Orange/Apple/Guava & 1 \\
\hline Blackberry (Jamun) & 1 bowl \\
\hline \multicolumn{2}{|l|}{ Lunch } \\
\hline $\begin{array}{c}\text { Salad (10 Mins Before } \\
\text { Lunch) }\end{array}$ & 1 medium bowl \\
\hline Capsicum + Gobhi Veg & 1 medium bowl \\
\hline \multicolumn{2}{|l|}{ Or } \\
\hline $\begin{array}{c}\text { Bitter- Gourd With Onion } \\
\text { Veg }\end{array}$ & 1 medium bowl \\
\hline Dal & 1 soup bowl \\
\hline Phulka (No Ghee) & 2 \\
\hline \multicolumn{2}{|l|}{ Evening } \\
\hline \begin{tabular}{|c|} 
Green Tea/Milk (Without \\
Sugar)/Herbal Tea/Lemon \\
Tea
\end{tabular} & 1 cup \\
\hline $\begin{array}{c}\text { Roasted Chana + Puffed } \\
\text { Rice OR Corn } \\
\end{array}$ & 1 cup \\
\hline \multicolumn{2}{|l|}{ Dinner } \\
\hline $\begin{array}{c}\text { Salad } 10 \text { Mins Before } \\
\text { Dinner) }\end{array}$ & 1 medium bowl \\
\hline Phulka ( No Ghee) & 2 \\
\hline Lauki Veg & 1 cup \\
\hline Curd & 1 cup \\
\hline Late Night & \\
\hline Skim Milk (Without Sugar) & 1 glass \\
\hline
\end{tabular}

Table 8: Follow up diet chart for obese patients.

\section{Data Collection Procedure}

Preliminary data was collected at the baseline (Day1) in a standardized format which included the information about daily routine of subjects, weight, height and Body Mass Index.

\section{Clinical measurements}

The measured value of weight and BMI range were compared with baseline and control group on day 1, day 15 , day 30 and for day 45.

\section{Measurement of Weight and Body Mass Index (BMI)}

Weight was measured by using electric weight balance by standing posture of the subject. Body mass index was measured as weight in kilograms divided by the square of their height in meter. Weight was measured while patients were wearing light clothing without shoes by using the weighing scale. Height measurement was taken using portable tape meter without shoes and recorded to the nearest $0.5 \mathrm{~cm}$.

\section{Ethical Consideration}

It was only an observational study. The diagnostic and treatment modalities given to patients was be recorded. Privacy of identity was maintained. The thesis proposal was reviewed and approved by the Institutional Ethical Committee (IEC) (Ref No: SMC/IEC/2017/194) of the Department of Pharmacology, Subhash Chandra Boss Subharti Medical College, Swami Vivekanand Subharti University, Meerut. The research started after ethical clearance was obtained.

\section{Results}

\section{Baseline (Day 1) Measurements of Weight and BMI of Subjects}

As can be seen in Table 9 at the beginning of the study both the Treatment and Control group had increased weight and BMI.

\begin{tabular}{|c|c|c|}
\hline \multicolumn{3}{|c|}{ Parameters } \\
\hline Baseline value & Treatment group & Control group \\
\hline Weight $(\mathrm{kg})$ & $69.5 \pm 12.3$ & $68.5 \pm 5.9$ \\
\hline BMI $\left(\mathrm{kg} / \mathrm{m}^{2}\right)$ & $33 \pm 3.5$ & $32.2 \pm 3.3$ \\
\hline
\end{tabular}

Table 9: Weight and BMI of patients measured on day 1. Data are expressed as mean \pm SD

\section{The Effect of Sprouted Fenugreek Seeds on Weight of Obese Patients}

Table 10,11,12 shows the weight of the treatment group on day 1, day 15, day 30 and day 45 following 


\section{Advances in Pharmacology and Clinical Trials}

administration of $25 \mathrm{gm}$ of sprouted fenugreek seeds in once a day. The data shows that weight of obese patients of the treatment group had significantly reduced weight as compared with baseline weight and with control group throughout the study period.
The treatment group was received sprouted fenugreek seeds for 45 consecutive days had decreased weight compared with baseline weight $1.4 \%(81.7 \pm 13.3$ vs. $80.5 \pm 13.1), 4 \%(81.7 \pm 13.3$ vs. $78.4 \pm 12.9)$ and $8.5 \%$ $(81.7 \pm 13.3$ vs. $74.7 \pm 12.4(\mathrm{P}<0.05))$ on day 15,30 and day 45 respectively.

\begin{tabular}{|c|c|c|c|c|c|}
\hline Groups & Day 1 & Day 15 & Mean Difference & T-value & P-value \\
\hline Treatment Group & $81.7 \pm 13.3$ & $80.5 \pm 13.1$ & $1.2 \pm 0.2$ & 0.34 & 0.72 \\
\hline Control Group & $75.5 \pm 6.1$ & $74.1 \pm 6.1$ & $1.4 \pm 0$ & 0.34 & 0.34 \\
\hline
\end{tabular}

Table 10: Weight $(\mathrm{kg})$ of obese patient of treatment and control group on day 1 and day 15.

\begin{tabular}{|c|c|c|c|c|c|}
\hline Groups & Day 1 & Day 30 & Mean Difference & T-value & P-value \\
\hline Treatment Group & $81.7 \pm 13.3$ & $78.4 \pm 12.9$ & $3.3 \pm 0.4$ & 0.94 & 0.34 \\
\hline Control Group & $75.5 \pm 6.1$ & $74.3 \pm 6.6$ & $1.2 \pm-0.5$ & 0.81 & 0.41 \\
\hline
\end{tabular}

Table 11: Weight (kg) of obese patient of treatment and control group on day 1 and day 30.

\begin{tabular}{|c|c|c|c|c|c|}
\hline Groups & Day 1 & Day 45 & Mean Difference & T-value & P-value \\
\hline Treatment Group & $81.7 \pm 13.3$ & $74.7 \pm 12.4$ & $7 \pm 0.9$ & 2.06 & 0.04 \\
\hline Control Group & $75.5 \pm 6.1$ & $73.8 \pm 6.2$ & $1.7 \pm-0.1$ & 1.15 & 0.25 \\
\hline
\end{tabular}

Table 12: Weight (kg) of obese patient of treatment and control group on day 1 and day 45 .

The treatment group shows statistically significant reduced weight when compared with the baseline weight

of the control group of obese patient.

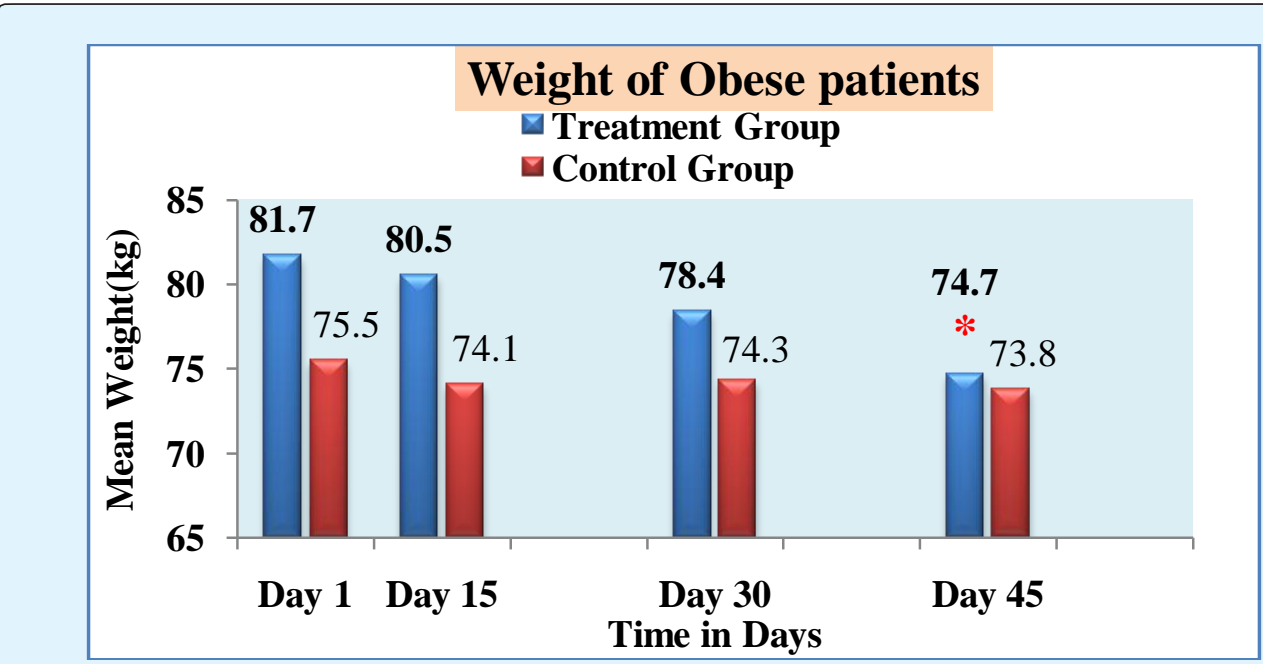

Figure 3: Weight of the treatment and control group on day 1, day 15, day 30 and day 45. The results are expressed as mean $\pm \mathrm{SD}$.

*Indicates significant differences ( $\mathrm{P}<0.05)$, treatment vs. control group on day 45.

Figure 3 demonstrated the treatment group was taken $25 \mathrm{gm}$ of sprouted fenugreek seeds once daily for (15) consecutive days, shows reduced weight when compared with the control group $81.7 \pm 13.3$ vs. $80.5 \pm 13.1(\mathrm{P}=0.72)$ on day 15. On day 30 , the treatment group received sprouted fenugreek seeds for 30 consecutive days had 


\section{Advances in Pharmacology and Clinical Trials}

decreased weight compared with control group $81.7 \pm 13.3$ vs. $78.4 \pm 12.9(\mathrm{P}=0.34)$. Similarly, on day 45 , the treatment group received sprouted fenugreek seeds for 45 consecutive days had statistically significant decreased weight compared with control group $81.7 \pm 13.3$ vs. $74.7 \pm 12.4(\mathrm{P}<0.05)$. However, the control group shows no significant change of weight measurement $75.5 \pm 6.1$ vs. $74.1 \pm 6.1(\mathrm{P}=0.34), 75.5 \pm 6.1$ vs. $74.3 \pm 6.6(0.41)$ and $75.5 \pm 6.1$ vs. $73.8 \pm 6.2(\mathrm{P}=0.25)$ compared with their baseline weight on day 15, 30 and day 45 respectively.

\section{The Effect of Sprouted Fenugreek Seeds on BMI}

Table 13,14,15 demonstrated the BMI of the treatment group on day 1, day 15, day 30 and day 45 following administration of $25 \mathrm{gm}$ of sprouted fenugreek seeds in once a day. The data shows that BMI of the treatment group had significantly lowered as compared with baseline BMI and with control group throughout the study period.

\begin{tabular}{|c|c|c|c|c|c|}
\hline Groups & Day 1 & Day 15 & Mean Difference & T-Value & P-Value \\
\hline Treatment Group & $33 \pm 3.5$ & $31.9 \pm 3.5$ & $1.1 \pm 0$ & 1.3 & 0.4 \\
\hline Control Group & $32.2 \pm 3.3$ & $32.1 \pm 3.2$ & $0.1 \pm 0.1$ & 0.23 & 0.93 \\
\hline
\end{tabular}

Table 13: BMI $\left(\mathrm{kg} / \mathrm{m}^{2}\right)$ of diabetic patient of treatment and control group on day 1 and day 15.

\begin{tabular}{|c|c|c|c|c|c|}
\hline Groups & Day 1 & Day 30 & Mean Difference & T-Value & P-Value \\
\hline Treatment Group & $33 \pm 3.5$ & $30.7 \pm 3.4$ & $2.3 \pm 0.1$ & 2.75 & 0.09 \\
\hline Control Group & $32.2 \pm 3.3$ & $31.7 \pm 3.9$ & $0.5 \pm-0.6$ & 0.7 & 0.68 \\
\hline
\end{tabular}

Table 14: BMI $\left(\mathrm{kg} / \mathrm{m}^{2}\right)$ of diabetic patient of treatment and control group on day 1 and day 30.

\begin{tabular}{|c|c|c|c|c|c|}
\hline Groups & Day 1 & Day 45 & Mean Difference & T-Value & P-Value \\
\hline Treatment Group & $33 \pm 3.5$ & $30.1 \pm 3.3$ & $2.9 \pm 0.2$ & 3.58 & 0.03 \\
\hline Control Group & $32.2 \pm 3.3$ & $31.8 \pm 3.1$ & $0.4 \pm 0.2$ & 0.59 & 0.74 \\
\hline
\end{tabular}

Table 15: BMI $\left(\mathrm{kg} / \mathrm{m}^{2}\right)$ of diabetic patient of treatment and control group on day 1 and day 45 .

The treatment group was received sprouted fenugreek seeds for 45 consecutive days had reduced BMI compared with baseline BMI $3.3 \%$ ( $33 \pm 3.5$ vs. $31.9 \pm 3.5)$, $6.9 \%$ $(33 \pm 3.5$ vs. $30.7 \pm 3.4)$ and $8.7 \%(33 \pm 3.5$ vs. $30.1 \pm 3.3(\mathrm{P} \leq$ $0.05)$ ) on day 15,30 and day 45 respectively. The treatment group shows statistically significant reduction in BMI range when compared with the baseline BMI range of diabetic patients. Day 1 was the baseline of the treatment and control group.

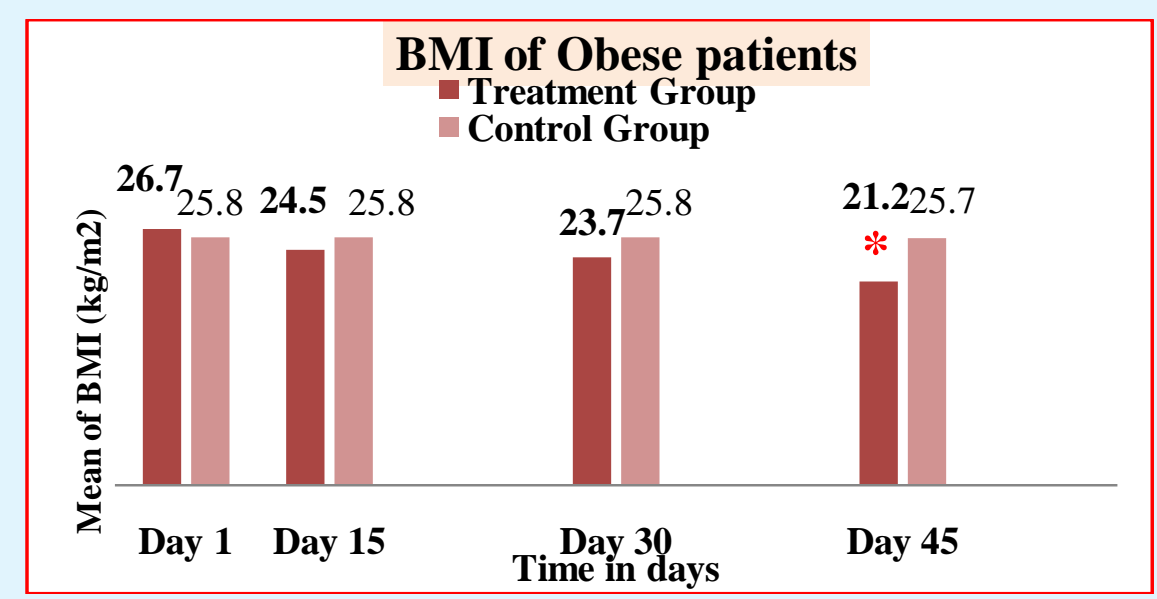

Figure 4: BMI of the treatment and control group on day 1, day 15, day 30 and day 45. The results are expressed as mean $\pm \mathrm{SD}$.

*Indicates significant differences ( $\mathrm{P}<0.05)$, treatment vs. control group on day 45. 


\section{Advances in Pharmacology and Clinical Trials}

As demonstrated in figure 4, the treatment group was taken $25 \mathrm{gm}$ of sprouted fenugreek seeds once a day for (15) consecutive days, shows reduced BMI when compared with the control group; $33 \pm 3.5$ vs. $31.9 \pm 3.5(\mathrm{P}=$ 0.4 ) on day 15. On day 30 , the treatment group received sprouted fenugreek seeds for 30 consecutive days had reduced BMI compared with control group $33 \pm 3.5$ vs. $30.7 \pm 3.4(\mathrm{P}=0.09)$. Similarly, on day 45 , the treatment group received sprouted fenugreek seeds for 45 consecutive days had statistically significant BMI compared with control group; $33 \pm 3.5$ vs. $30.1 \pm 3.3$ (P < $0.03)$. However, the control group which had not received sprouted fenugreek seeds shows no significant change in BMI $32.2 \pm 3.3$ vs. $32.1 \pm 3.2(\mathrm{P}=0.93), 32.2 \pm 3.3$ vs. $31.7 \pm 3.9$ $(\mathrm{P}=0.68)$ and $32.2 \pm 3.3$ vs. $31.8 \pm 3.1(\mathrm{P}=0.74)$ compared with their baseline BMI on day 15, 30 and day 45 respectively.

\section{Discussion}

Obesity is one of the major problem for future prevalence. Millions of people are dying due to obesity and obesity related risk factors. These factors include development of cardiovascular, endocrine disorders and neuropathic complications. These complication are come due to change in lifestyles, reduce physical work, not get time to walk and excessive eating (fast foods). To overcome this problem and to cure of this morbidity complication; sprouted fenugreek seeds is the best example for reducing excessive weight and body mass index of the patients.

Sprouted fenugreek seeds have desired active ingredients for reduce extra weight and improved the glucose tolerance in the body. There are three main active constituents that are responsible for its action i.e. galactomannans (fibers), 4-hydroxyisoleucine acid and trigonelline. These components slower down the absorption of sugar and fat in stomach and intestine and to lower the entry of these molecules in to blood stream. Besides that galactomannan act on extra-pancreatic route inhibits the production of glycogenolysis in liver and ameliorates histological damage in the $\beta$ cells of Langerhans. As a result the new sugar molecule is not generated and nor to stored in the muscles.

Fenugreek sprouts increase the amount of HDL-C in the blood and lowers triglycerides, LDL-C and VLDL due to its availability of high amount of protein called 4hydroxyisoleucine acid and also fibers in it.

Firoz Khan and Prem Parkash Khosala. To Study the Effect of Sprouted Fenugreek Seeds Along with Yoga and Diet Modification on Obese Patients. Adv Pharmacol Clin Trials 2018, 3(3): 000138.
In addition to its anti-hyperglycemic effect, sprouted fenugreek seeds reduced the excessive weight of obese patients. In this study weight was significantly reduced in treatment group by administration of 25 gm sprouted fenugreek seeds once daily for 45 consecutive days. It significantly reduced body weight $(\mathrm{p}<0.05)$ compared with control groups (figure 3).

The current study demonstrated the reduction of both men and women body mass index after taken the sprouted seeds of fenugreek for 45 days. The reduction of BMI was statistically significant $\mathrm{P}=<0.05$ had shown in figure 4 . The study demonstrated the reduction in BMI due to its proteins and fibers and also enhanced the gastric empting time.

\section{Conclusion}

Trigonelline, 4-Hydroxyisoleucine and fibers are thee of the main constituent that are responsible for reduction of excessive body weight and BMI of the subjects. In this article it was proved that modification in the diet and applying Yoga in the daily routine reduced the risk of obesity and related metabolic disease that helps to human live longer.

\section{References}

1. Francisco Paula JA, Clifford JR (2010) Obesity, diabetes mellitus and last but not least, osteoporosis. Arq Bras Endocrinol Metab 54(2): 149-157.

2. Cutrim DM, Pereira FA, Paula FJ, Foss MC (2007) Lack of relationship between glycemic control and bone mineral density in type 2 diabetes mellitus. Braz J Med Biol Res 40(2): 221-227.

3. Reis JP, Hankinson AL, Loria CM, Lewis CE, Powell Wiley T, et al. (2013) Duration of abdominal obesity beginning in young adulthood and incident diabetes through middle age: the cardia study. Diabetes Care 36(5): 1241-1247.

4. Yaturu S (2011) Obesity and type 2 diabetes. Journal of Diabetes Mellitus 1(4): 79-95.

5. Garrow JS (1988) Obesity and Related Diseases. London, Churchill Livingstone 1-16.

6. Aftab SA, Reddy N, Smith E, Barber TM (2012) Obesity and Type 2 Diabetes Mellitus. Internal Medicine: Open Access 2(6): 1-6. 


\section{Advances in Pharmacology and Clinical Trials}

7. Van IT (1998) Health implications of over-weight and obesity in the United States. Annals of Internal Medicine 103: 983-988.

8. Schwartz AV, Sellmeyer DE, Ensrud KE, Cauley JA, Tabor HK, et al. (2001) Older women with diabetes have an increased risk of fracture: a prospective study. J Clin Endocrinol Metabol 86(1): 32-38.

9. Thorpe SR, Baynes JW (2003) Maillard reaction products in tissue proteins: new products and new perspectives. Amino Acid 25(3-4): 275-281.

10. Thornalley PJ, Langborg A, Minhas HS (1999) Formation of glyoxal, methylglyoxal and 3deoxyglucosone in the glycation of proteins by glucose. Biochem J 344: 109-116.

11. Yao D, Taguchi T, Matsumura T, Pestell R, Edelstein D, et al. (2007) High glucose increases angiopoietin-2 transcription in microvascular endothelial cells through methylglyoxal modification of mSin3A. J Biol Chem 282(42): 31038-31045.
12. Saito M, Fujii K, Soshi S, Tanaka T (2006) Reductions in degree of mineralization and enzymatic collagen cross-links and increases in glycation-induced pentosidine in the femoral neck cortex in cases of femoral neck fracture. Osteoporos Int 17(7): 986-995.

13. Saito M, Fujii K, Marumo K (2006) Degree of mineralization-related collagen crosslinking in the femoral neck cancellous bone in cases of hip fracture and controls. Calcif Tissue Int 79(3): 160-168.

14. Sadeghzadeh Ahari D, Kashi AK, Hassandokht MR, Amri A, Alizadeh Kh (2009) Assessment of drought tolerance in Iranian fenugreek landraces. Journal of Food, Agriculture \& Environment 7(3,4): 414-419.

15. Sauvaire Y, Petit P, Broca C (1998) 4Hydroxyisoleucine: a novel amino acid potentiator of insulin secretion. Diabetes mag 47(2): 206-210.

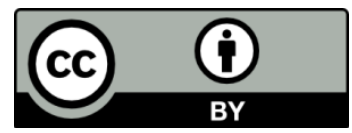

Firoz Khan and Prem Parkash Khosala. To Study the Effect of 